\title{
Development and participatory evaluation of fireline intensity and flame property models for managed burns on Calluna- dominated heathlands
}

\author{
G. Matt Davies ${ }^{1,2^{*}}$, Colin J. Legg ${ }^{2}$, A. Adam Smith ${ }^{3}$ and Angus MacDonald ${ }^{4}$
}

\begin{abstract}
Background: Prescribed burning plays an important role in the management of many ecosystems and can also be used to mitigate landscape-scale fire risk. Safe and effective application of prescribed fire requires that managers have a robust understanding of potential fire behavior in order to decide on the appropriate tools and tactics for any burning operation. Shrubland ecosystems, including heaths and moors, are known to exhibit intense fire behavior under marginal burning conditions under which fire would not be expected to spread in other vegetation types. This makes developing fire behavior predictions for such systems important. Traditional managed burning is widely used as a tool in Calluna vulgaris (L.) Hull-dominated heath and moorland landscapes in northwest Europe, but in some regions, especially the United Kingdom, there is significant debate over fire use. Despite the controversy, there is general agreement on the need to (1) understand relationships between fuel structure and potential fire behavior, and (2) improve burning practice to optimize potential trade-offs between different ecosystem services. Our aim was to provide knowledge to improve management practice by developing models of potential fireline intensity and flame length. We conducted 27 burns in three developmental stages of Calluna with different stand structures and estimated fireline intensity, flame length, flame height, and flame angle. Flame properties were assessed using photographs and visual observation. We evaluated our models using a participatory research approach for which conservation and land managers submitted basic observations on fire behavior and fire weather for their burns.

Results: Fireline intensity and flame height increased significantly across age-related Calluna phases. Regression modeling revealed that fireline intensity could be adequately estimated by a combination of fuel height and wind speed, with taller fuels and higher wind speeds related to more intense fires. Predictions were, however, improved by accounting for live fuel moisture content. Flame length and height were modeled as a function of fireline intensity using standard approaches, but adequately performing models for flame angle could not be established. Evaluation data provided by land managers was noisy, but their qualitative assessments of fire behavior and estimates of flame length were significantly correlated with predictions from our models.

(Continued on next page)
\end{abstract}

\footnotetext{
* Correspondence: davies.411@osu.edu

${ }^{1}$ The Ohio State University, School of Environment and Natural Resources, Kottman Hall, 2021 Coffey Road, Columbus, Ohio 43210, USA

${ }^{2}$ The University of Edinburgh, School of GeoSciences, Crew Building, The

King's Buildings, Alexander Crum Brown Road, Edinburgh EH9 3FF, Scotland

Full list of author information is available at the end of the article
} 
(Continued from previous page)

Conclusions: Fire intensities and flame properties seen in northern Calluna heathlands are similar to those encountered in shrublands associated with climates and fuels more commonly perceived as representing high fire danger. The results demonstrated that our models perform tolerably well although there is substantial uncertainty in their predictions. The models were used to develop a fire behavior nomogram that can provide an indication of potential fireline intensity and flame length prior to commencing a burn.

Keywords: citizen science, empirical model, fire behavior, flame angle, flame height, flame length, managed burning, moorland, nomogram, prescribed fire

\section{Resumen}

Antecedentes: Las quemas prescriptas juegan un rol importante en el manejo de varios ecosistemas y pueden también ser usadas para mitigar el riesgo de incendio a escala de paisaje. La aplicación efectiva y segura del fuego prescripto requiere que quienes lo aplican tengan un conocimiento robusto del comportamiento potencial del fuego para poder decidir sobre las tácticas y herramientas apropiadas en cualquier operación de quema. Los ecosistemas de arbustales, incluyendo brezales y páramos, son conocidos por exhibir un comportamiento de fuego intenso en condiciones marginales, bajo las cuales el fuego no se propagaría en otros ecosistemas. El manejo tradicional de quemas es ampliamente usado como una herramienta de manejo en Calluna vulgaris (L.) Hull dominados por brezales y páramos en el noroeste de Europa, aunque en algunas regiones, especialmente en el Reino Unido, hay un debate significativo sobre el uso del fuego. A pesar de esa controversia, hay un consenso general sobre: 1) entender las relaciones entre estructura del combustible y comportamiento potencial del fuego, y

2) mejorar las prácticas de quemas para optimizar el potencial balance entre diferentes servicios ecosistémicos. Nuestro objetivo fue proveer del conocimiento para mejorar las prácticas de manejo mediante el desarrollo de modelos de intensidad de línea y longitud de llama. Condujimos 27 quemas en tres estados de desarrollo de Calluna en stands con diferentes estructuras, y estimamos intensidad de línea, longitud de llama, altura de llama, y ángulo de llama. Evaluamos nuestro modelo mediante la aproximación a una investigación participativa para la cual conservacionistas y manejadores de tierras enviaron observaciones básicas sobre comportamiento y meteorología del fuego de sus quemas.

Resultados: La intensidad de línea y la altura de llama se incrementaron significativamente a través de las fases relacionadas con la edad de Calluna. Los modelos de regresión revelaron que la intensidad de línea puede ser adecuadamente estimada mediante una combinación de la altura del combustible y la velocidad del viento, con combustibles más altos y mayores velocidades de viento relacionadas con fuegos más intensos. Las predicciones fueron por supuesto mejoradas cuando se tuvo en cuenta la humedad del combustible vivo. La longitud y altura de llama fueron modeladas usando aproximaciones standard, aunque aun usando modelos adecuados no fue posible establecer el ángulo de llamas. La evaluación de los datos provistos por manejadores de tierras fue intrincado, aunque las determinaciones cualitativa del comportamiento del fuego y las estimaciones de longitud de llama se correlacionaron significativamente con predicciones de nuestros modelos.

Conclusiones: Las intensidades de fuego y las propiedades de las llamas observadas en los brezales de Calluna del norte son similares a aquellos encontrados en arbustales asociados con climas que se perciben como representativos de un alto grado de peligro. Los resultados demostraron que nuestros modelos se comportan de manera aceptable, aunque hay cierto grado de incertidumbre en sus predicciones. Los modelos fueron usados para desarrollar un nomograma de comportamiento que puede proveer una indicación de la intensidad potencial de la línea de fuego y de la longitud de llama antes de comenzar con la quema. 


\section{Background}

Prescribed burning plays an important global role in protecting and enhancing a range of ecosystem services including the maintenance of fire-dependent ecosystems and their associated biodiversity (e.g., Brockett et al. 2001; Burrows and McCaw 2013; Fernandes et al. 2013). Prescribed fire is also a critically important tool in the management of landscape-scale wildfire risk and is widely used in fuel treatment operations (Fernandes and Botelho 2003; van Mantgem et al. 2016; Espinosa et al. 2019). For prescribed burns to be implemented safely and effectively, fire managers need to have reliable information on likely fire behavior. Fire behavior is characterized by a wide variety of metrics but, from a fire-control perspective, fireline intensity, rate of spread, and flame properties are particularly important. Fireline intensity (the rate of heat output per unit length of fireline; $\mathrm{kW} \mathrm{m}^{-1}$ ) has been linked to the efficacy of different fire control tools and strategies (Hirsch and Martell 1996), the height and intensity of tree scorch in forests (Van Wagner 1973), and the potential for crown fire initiation (Alexander and Cruz 2011). Flame properties, including height, length, and angle, are also important in determining processes such as maximum fire spotting distance (Albini et al. 2012), crown fire potential (Alexander and Cruz 2011), and minimum fire break widths (Wilson 1988). Importantly, previous research (e.g., Byram 1959; Thomas 1963, Nelson and Adkins 1986; Anderson et al. 2006) has shown that fireline intensity and mean flame length are closely related. This means that flame lengths can provide an important visual signal of the controllability and potential ecological effects of fires. There has been significant empirical and quantitative work in modeling flame properties and fireline intensity, and a number of fire behavior simulators now exist (Papadopoulos and Pavlidou 2011). From such research we know that the effects of variation in fire weather on flame characteristics and fireline intensity are dependent upon fuel type. It is thus important for fire managers to understand the fuelfire weather-fire behavior relationships for the systems within which they work.

Shrubland ecosystems, such as heathlands and moorlands, have posed particular challenges for fire behavior modeling as they can burn at high intensities even under weather conditions for which fires would normally be expected to only have a marginal probability of being self-sustaining. We know from previous studies that important controls on shrubland fire behavior include fuel loading and structure (Brown and Bevins 1986; Fernandes 2001), fuel height (Catchpole et al. 1998; Fernandes et al. 2000), fuel moisture (Pompe and Vines 1966; Sylvester and Wein 1981), the quantity of dead fuel present (Baeza et al. 2002), windspeed (Molina and Llinares 1998; Morvan et al. 2002; Bilgili and Saglam 2003), relative humidity (Molina and Llinares 1998), topography of the fire site (Fernandes et al. 2002), and ignition line length (Hobbs and Gimingham 1984; Cheney et al. 1993). Many shrubland ecosystems contribute significantly to landscape-scale fire risk (e.g., Moreira et al. 2011), but they may also be fire-dependent ecosystems in which prescribed fire, or traditional managed burning, plays an important role in maintaining their ecological structure and function (Fagúndez 2013; Fernandes et al. 2013). This is particularly the case in the uplands of the United Kingdom where managed burning is widely used to manage grass and dwarf-shrubdominated ecosystems for a range of agricultural, game hunting, and conservation purposes (Davies et al. 2008). Managed burning of upland vegetation may also help to minimize both the risk of wildfires and the loss of carbon when wildfires do occur (Allen et al. 2013; Santana et al. 2016). Similar management practices are used to maintain ecologically-important Calluna heathlands throughout Europe (e.g. Vandvik et al. 2014, Ascoli and Bovio 2013).

Traditional managed burning in the United Kingdom, known in Scotland as "muirburn," is most associated with patch burning of Calluna vulgaris (L.) Hull (hereafter Calluna)-dominated habitats. The objective of such management is generally to produce a mosaic of small (circa $30 \mathrm{~m}$ ) fires to improve grazing for sheep and deer and to provide diverse habitat structures that benefit feeding and nesting of red grouse (Lagopus lagopus scotica Latham, 1787) and other birds (Pearce-Higgins and Grant 2006; Robertson et al. 2017). In the U.K. there is, however, considerable controversy over the effects of this management practice due to (1) failure to adequately account for interactions between multiple disturbances including drainage, grazing, nutrient deposition, and fire (Davies et al. 2016a; Noble et al. 2018); (2) lack of recognition of the resilience of keystone peatland species, such as Sphagnum L. spp., to fire (Grau et al. 2017; Taylor et al. 2017); and (3) unquantified trade-offs between multiple ecosystem services such as carbon sequestration in organic and peat soils (Ward et al. 2007), regulation of catchment hydrology and water quality (Holden et al. 2012; Brown et al. 2013), agricultural and game production, and the conservation of unique moorland biodiversity (Thompson et al. 1995). Attention has also been focused by recent severe wildfires (e.g., Davies et al. 2016b), which have the potential to drive long-lasting changes in the ecological function of these peatland systems (Maltby et al. 1990).

It is increasingly apparent that managers and landscape planners require a better sense of fuel and weather controls on fire behavior to identify safe periods for prescribed burning and optimize landscapes for wildfire risk reduction. Empirical modeling has played a vital role in enhancing understanding of controls on fire behavior 
(Sullivan 2009). To date, research on fire behavior in Calluna-dominated ecosystems has provided models of fire rate of spread (Davies et al. 2009), assessment of how fire weather relates to the occurrence of wildfires (Davies and Legg 2016; de Jong et al. 2016), and assessment of variation in fire temperatures and fire-induced heating both within the Calluna canopy (e.g., Hobbs and Gimingham 1984), and at and below ground level (Grau-Andrés et al. 2017).

Models of fireline intensity and flame properties are needed for heathland fuel types to help identify safe periods for prescribed burning, and to plan for prescribed and wild fires through the creation of firebreaks (Log et al. 2017). To date, a key limitation on the development and evaluation of fire behavior models has been the cost and logistical difficulties associated with completing experimental burn programs. Whilst burn experiments yield vital quantitative data, additional information might be available through participatory research. Citizen science approaches (i.e., data collection by members of the public including project stakeholders in collaboration with researchers) have proven to be an effective means to accumulate large amounts of data on environmental and ecological phenomena (Dickinson et al. 2010). With large numbers of individual gamekeepers, conservationists, and other land managers utilizing managed burning in the United Kingdom, there is an opportunity to collate and analyze their observations of variation in fire behavior, to use this to evaluate fire behavior models, and to generate a sense of "buy-in" to, or ownership of, the model development process.

The broad aim here was to develop empirical models of fireline intensity and flame properties (length, height, and angle) of fires burning in Calluna-dominated fuels. The specific objectives were to: (1) assess differences in fire behavior among age-related Calluna fuel classes; (2) use experimental burns to develop empirical models of fireline intensity as a function of fire weather and fuel characteristics; (3) use the same burns to model flame length, height, and angle as a function of fireline intensity and compare results obtained here with existing models; and (4) evaluate the performance of our models using participatory citizen science data on fire behavior collected by managers independently completing prescribed burns.

\section{Methods}

\section{Experimental design}

To develop empirical fire behavior models, experimental burns were used to generate data on fireline intensity, flame properties, and associated fuel and fire weather conditions. Experimental burns were set up at two sites: Crubenmore Estate, near Dalwhinnie on the edge of the Cairngorms National Park in northeast Scotland (56.947
N, 4.239 W; Ordnance Survey National Grid reference NN6386), and Black Hill, Whitborough Estate, in the Pentlands outside Edinburgh (55.855 N, 3.303 W; Ordnance Survey National Grid reference NT1862). All plots had slopes of $<10 \%$, and the vegetation prior to burning was Calluna-dominated upland heath composed mostly of closed stands of Calluna vulgaris with Vaccinium myrtillus L. and Vaccinium vitis-idaea L. commonly occurring beneath the canopy (National Vegetation Classification community H12, Calluna vulgaris-Vaccinium myrtillus heath, Rodwell 1991). Stands contained a mixture of coarse grasses and sedges with Trichophorum germanicum Palla, Deschampsia flexuosa (L.) Trin., and Molinia caerulea (L.) Moench being frequent but never forming a significant proportion of the fuel load. Most stands were underlain by more or less continuous mats of pleurocarpous mosses.

The experiment utilized a randomized block design in which burn days were the blocking variable. To ensure that we captured a representative range of fire behavior conditions, each block consisted of three plots classified as belonging to the early-building, late-building, or mature phases of the Calluna cycle, as described by Gimingham (1988). Previous research (Davies et al. 2009) has demonstrated significant differences in fuel load, height, and bulk density between these fuel classes. Mean total fuel load varied from $0.85 \mathrm{~kg} \mathrm{~m}^{-2}$ (range: 0.42 to $1.22 \mathrm{~kg} \mathrm{~m}^{-2}$ ) in early-building stands, to $1.23 \mathrm{~kg} \mathrm{~m}^{-2}$ (range: 1.02 to $1.22 \mathrm{~kg} \mathrm{~m}^{-2}$ ) in late-building stands, and to $1.45 \mathrm{~kg} \mathrm{~m}^{-2}$ (range: 0.99 to $1.95 \mathrm{~km} \mathrm{~m}^{-2}$ ) in mature fuels. Mean fuel height ranged from $0.19 \mathrm{~m}$ (range: 0.12 to 0.27 $\mathrm{m}$ ) in early-building phase fuels, to $0.28 \mathrm{~m}$ (range: 0.20 to $0.30 \mathrm{~m}$ ) in the late-building phase, and to $0.40 \mathrm{~m}$ (range: 0.23 to $0.51 \mathrm{~m}$ ) in the mature phase. There was noticeably more intra-stand variation in the structure of mature fuels with significant canopy gaps and greater spatial heterogeneity in loading and height. One block (i.e., three plots, one in each of the Calluna phases) was burned each day. A total of nine burn days were completed, giving 27 individual fires in total. Twenty-one plots were burned at Crubenmore while six were burnt at Black Hill.

Plot dimensions differed between the two research sites ( $15 \mathrm{~m}$ wide by $20 \mathrm{~m}$ long at Crubenmore; $20 \mathrm{~m}$ by $20 \mathrm{~m}$ at Black Hill). All plots were surrounded by $>5 \mathrm{~m}$ mown, or mown and back-burned, firebreaks. The layout of measurements and monitoring equipment also differed slightly between the sites. Full details including monitoring design schematics are provided in Davies et al. (2009). All fires were ignited as a line ignition using a drip torch and were burned as head fires (i.e., in the same direction as the prevailing wind, as is usual for managed heath and grass fires in the United Kingdom).

We assessed fuel loads before and after the fires. Prior to burning, fuel loading was assessed using the FuelRule 
method, described in full in Davies et al. (2008). Briefly, the FuelRule uses a $2 \mathrm{~m}$ long measuring stick painted with alternating yellow and white bands. Observers record the height and proportion of each band that is visually obscured when the stick is held vertically in the vegetation at arm's length. Analyzing how the proportion of each band obscured changes with height allows the calculation of a number of indices that can be correlated with fuel load and structure. FuelRule readings were taken $2 \mathrm{~m}$ apart on either three or four $15 \mathrm{~m}$ long transects with the resulting mean structural indices used to estimate loading via the equations provided in Davies et al. (2008). Post-fire biomass was estimated by destructively harvesting 2 to $3,50 \times 50 \mathrm{~cm}$ quadrats in each plot. Fuel samples were dried for 48 hours at $80{ }^{\circ} \mathrm{C}$ before being weighed. Rate of spread was measured using thermocouple arrays (twisted pair K-type thermocouples connected to a Campbell 21X data logger [Campbell Scientific Ltd, Loughborough, United Kingdom], 2 s logging interval) or manual timing of fire-front travel between $2.5 \mathrm{~m}$ high measuring posts spaced $5 \mathrm{~m}$ apart. Specific details on methods used to assess rate of spread, and the resulting spread patterns observed for these fires, are described in Davies et al. (2009). Variation in fuel consumption data are discussed in Davies et al. (2016b).

A portable meteorological station (Skye Instruments Ltd, Llandrindod Wells, Wales) was located roughly 50 $\mathrm{m}$ to the rear of each fire. The weather station recorded wind speed and direction, temperature, and humidity. Wind speed was measured at $1.5 \mathrm{~m}$ above ground level, which was judged to roughly equate to mid-flame height. Data logging began at least 15 minutes prior to ignition and, on most days, data was recorded as 10-second averages. Unfortunately, for the fires at Crubenmore, on one day it was only possible to retrieve data at 10-minute intervals, while on four days the data collected were corrupted and unusable. In the latter case, hourly means for the required information were available from a fixed weather station (Campbell Scientific Ltd.) located some $10 \mathrm{~km}$ to the east-northeast (51.032 N, $4.153 \mathrm{~W}$; Ordnance Survey National Grid reference NN 6995) at a similar altitude. Wind speed data from the base station were calibrated for use at the experiment site by regression relationships established over two calibration periods. The two stations collected data at the same monitoring interval as the roving station that was located centrally within the experiment area. Details of the calibration procedure are given in Davies (2006). Fuel moisture samples were taken prior to all fires and were dried in an oven at $80{ }^{\circ} \mathrm{C}$ for 48 hours. Initially, four samples were taken of both canopy shoots (containing an intimate mixture of live and dead material) and the top $2 \mathrm{~cm}$ of the moss and litter layer. For subsequent fires (2006 onwards), five samples of live canopy shoots, dead stems with dead foliage, and the top $2 \mathrm{~cm}$ of the moss and litter layer were collected from the center of randomly selected subplots.

\section{Quantifying fireline intensity of experimental fires}

Fireline intensity was calculated as the product of heat of combustion, fuel consumption, and fire rate of spread as per Byram's (1959) equation. High heat of combustion was set at a value of $20810 \mathrm{~kJ} \mathrm{~kg}^{-1}$, which is the mean of the values measured by Hobbs (1981) for Calluna shoots and woody stems $\left(21350 \mathrm{~kJ} \mathrm{~kg}^{-1}\right.$ and $20270 \mathrm{~kJ} \mathrm{~kg}^{-1}$, respectively). This value was reduced by $1263 \mathrm{~kJ} \mathrm{~kg}^{-1}$ to account for latent heat absorbed by the vaporization of the water of reaction (Byram 1959) and by a further $24 \mathrm{~kJ} \mathrm{~kg}^{-1}$ per fuel moisture content percentage point (Van Wagner 1973).

\section{Estimating flame properties during experimental fires}

Flame properties were assessed via reference to $2.5 \mathrm{~m}$ high reference posts that were centrally located down the middle of each fire (Fig. 1). Cross beams at heights of 1 and $2 \mathrm{~m}$ allowed flames to be judged against a constant reference point. The posts were also used to visually estimate flame height to the nearest $25 \mathrm{~cm}$, with three estimates made when the fire reached each post. Multiple photographs were also taken as the fire approached each post, and these were used to produce separate estimates of flame length and flame angle by trigonometry. Flame length in photographs was measured from the mid-point of the flame base to the tip of the continuous flame area (Anderson et al. 2006), discounting any disjunct areas of flame above the main body. Flame angle was estimated as the displacement of the flames from the upright monitoring post. Due to camera malfunction, photographs were not available for seven fires. Preliminary analysis suggested that visual observation of flame height tended to consistently underestimate flame lengths compared to photographic analysis. We developed a regression equation relating flame length to visually observed flame height $\left(R^{2}\right.$ adj $\left.=0.42\right)$ and used this to estimate flame length when photographs were missing.

\section{Model development: fireline intensity and flame properties}

All data analysis was completed in R 3.5.0 (R Core Team 2018) using base statistical functions and the packages leaps (Lumley and Miller 2017) and userfriendlyscience (Peters 2018). Due to unequal variances between Calluna stages, we used Welch's one-way test (function = oneway.test) to assess evidence for significant differences among fuel classes in fireline intensity, flame length, and flame height. Post-hoc pairwise comparisons were made using the posthoc.tgh function in userfriendlyscience. We also examined the level of correlation between rate of spread and 


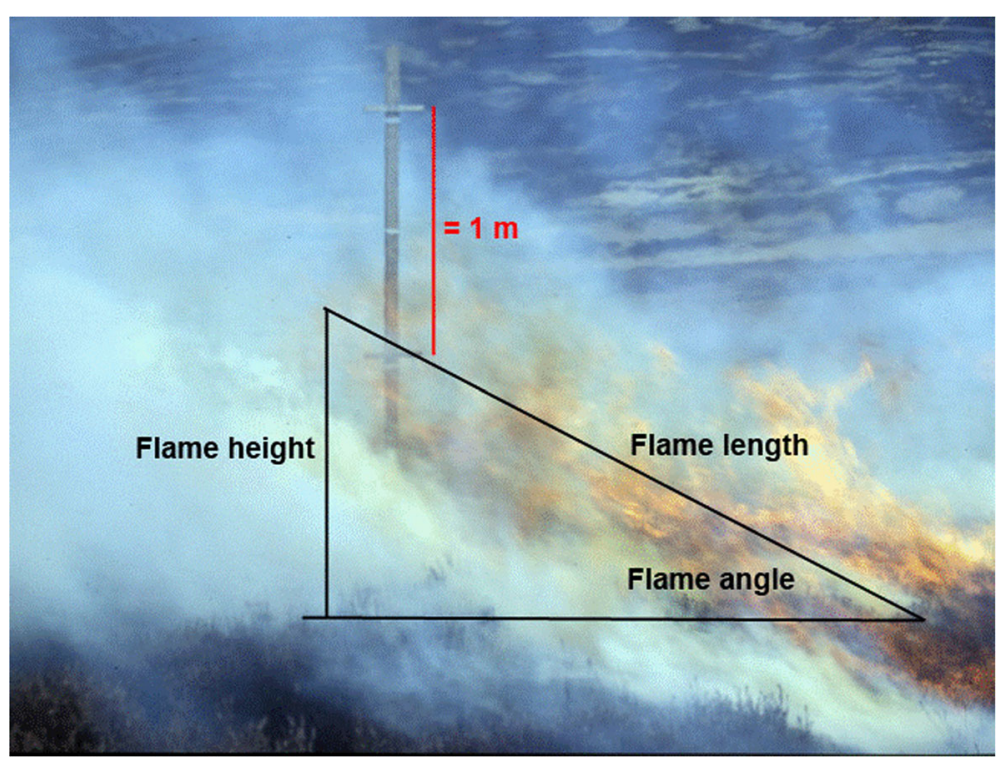

Fig. 1 Example of measurement of flame properties from a fire monitoring photograph. Flame height, length, and angle are illustrated. The reference post with cross-bars at 1 and $2 \mathrm{~m}$ can be seen in the background. Flame angle was generally measured as the angle between the ground surface and the flame front. For our experimental managed burns on Calluna-dominated moorland in Scotland between spring 2006 and autumn 2009, this was converted to the angle off set from vertical for analytical purposes as per Taylor (1961) and Albini (1981)

fireline intensity (function cor . test). Fireline intensity (I) was modeled using best subsets regression via the regsubsets function in leaps. We included fuel load, fuel height, fuel bulk density, live Calluna fuel moisture content, and wind speed as predictors. Additionally, we included a term composed of the product of fuel height squared and wind speed, as previous research (Davies et al. 2009) had demonstrated this to be the best predictor of rate of spread for the same set of fires. The best selected models were fitted via linear model implemented using the $1 \mathrm{~m}$ function.

Empirical modeling of flame properties followed the procedures described in the review by Anderson et al. (2006). A summary of these methods is provided below. A single plot that did not burn was excluded from these analyses. All models were fitted based on flame properties derived from photographs using the $1 \mathrm{~m}$ function in $R$. For seven fires for which flame length was not observable, we estimated flame length based on its relationship with visually observed flame height. We modeled flame length ( $\mathrm{L}$ ) as a function of fireline intensity using an equation with the form $L=a I^{b}$. This form of model has shown strong performance across a range of fuel types in previous research (Anderson et al. 2006). We compared our results to key models published by previous researchers including Byram's (1959) original version; Thomas (1963), who burned spruce cribs; Fernandes et al.'s (2000) model for shrubland fires in Portugal; and Nelson and Adkins (1986) model for fires in pine needle beds. We fitted log-log models using the $\mathrm{lm}$ function in
$\mathrm{R}$ and transformed the resulting models into power equations. Visually observed flame height was modeled using $I / U$ as the predictor as per Nelson and Adkins (1986).

Flame angle $\left(\alpha_{\mathrm{a}}\right)$ was modeled as the deflection of the flame body from an upright position (i.e., $90-\alpha$; Fig. 1) based on the equations presented by Taylor (1961) and Albini (1981). Taylor's model related flame angle to fireline intensity and windspeed:

$$
\tan (\alpha)=a\left(\frac{U^{3}}{I}\right)^{\mathrm{b}}
$$

where: $\alpha=$ flame angle (degrees), $U=$ wind speed $\left(\mathrm{m} \mathrm{s}^{-1}\right)$, and $I=$ fireline intensity $\left(\mathrm{kW} \mathrm{m}^{-1}\right)$.

Albini's model related flame angle to a Froude number based on wind speed and flame height:

$$
\tan (\alpha)=a\left(\frac{U^{2}}{g H}\right)^{\mathrm{b}}
$$

where: $\alpha=$ flame angle (degrees), $U=$ wind speed $\left(\mathrm{m} \mathrm{s}^{-1}\right)$, $g=$ gravimetric constant $\left(9.8 \mathrm{~m} \mathrm{~s}^{-1}\right)$, and $H=$ flame height $(\mathrm{m})$

We fitted $\log$-log models using the $\mathrm{lm}$ function in $\mathrm{R}$ and transformed the resulting models into power equations. Additionally, we used best subsets (function regsubsets) to model $\alpha_{\mathrm{a}}$ using the same suite of predictors as for modeling of fireline intensity; however, we also included the parameters defined by Taylor (1961) 
and Albini (1981). The best resulting models were fitted using the $1 \mathrm{~m}$ function.

\section{Participatory evaluation of fire behavior models}

Completion of experimental burning programs is logistically and financially challenging, and it is often difficult to produce sufficient data to allow for both model development and verification. To generate data for evaluation of our fire behavior models produced using the data and methods previously described, we distributed simple fire behavior recording cards to managers who were independently completing managed burns. Participants included gamekeepers and other managers of private land, reserve managers from the Royal Society for the Protection of Birds, and site managers from the Forestry Commission. Participants were asked to record a number of parameters including basic weather conditions (wind speed, measured on a Beaufort scale adapted for open moorland conditions, wind direction, time since last rain, cloud cover), vegetation type and height, flame length, and fire control resources. Fireline intensity is closely linked to thresholds of fire controllability. In lieu of formal assessment of fire behavior, not possible during regular managed burning operations, managers were asked to use clearly described five-point scales to rate "ease of ignition" ( $1=$ would not light despite repeated attempts with backpack driptorch; and $5=$ can be easily lit with cigarette lighter alone, fires spread from spot ignitions) and "difficulty of control" ( $1=$ no control necessary as fire self-extinguishes, and $5=$ fire rapidly escapes all control or would have were it not for firebreaks). An example of the recording card is provided in Additional file 1.

To evaluate our models, we treated "ease of control" reported by participants as an indicator of fireline intensity and examined the relationship between this and fireline intensity estimated by our models. Using correlation analysis (function $=$ cor.test), we also examined the relationship between average or maximum flame lengths reported by managers and flame length predicted by our model. Kendall's rank correlation (cor.test) was used to examine the relationship between ease of ignition and difficulty of control.

\section{Results}

\section{Variation in fire behavior across Calluna phases}

We burned 27 fires that captured a wide range of conditions from a single plot with a fuel load that proved too low to support fire spread $\left(4.2 \mathrm{tha}^{-1}\right)$, to successful ignitions with eventual fireline intensities that varied by an order of magnitude. For the sustaining fires, fireline intensity varied from $137 \mathrm{~kW} \mathrm{~m}^{-1}$ to $4056 \mathrm{~kW} \mathrm{~m}^{-1}$ and averaged $1196 \pm 1072 \mathrm{~kW} \mathrm{~m}^{-1}$ ( \pm 1 standard deviation). There were significant differences $\left(F_{2,14.8}=5.35, P=\right.$ 0.02) in mean fireline intensity between the three fuel classes; however, post-hoc analysis showed that these only existed between the mature and early-building fuel classes (Fig. 2). Fireline intensities were highest in the mature fuel class, but it was also noticeable that intensities in this class showed very substantial variation.

Across all sustaining experimental fires, flame lengths averaged $1.65 \pm 0.60 \mathrm{~m}$ ( \pm 1 standard deviation), with both the longest $(2.80 \mathrm{~m})$ and shortest $(0.43 \mathrm{~m})$ observed in early-building phase plots. Flame lengths were generally higher in mature and late-building fuel classes than in the early-building phase plots, but the differences between fuel classes were not statistically significant $\left(F_{2,13.66}=1.27, P=0.31\right.$; Fig. 2$)$.

\section{Fireline intensity modeling}

Fireline intensity was well predicted by a combination of fuel height and wind speed $\left(h^{2} U\right)$. The addition of live fuel moisture content to the model substantially improved the model fit (Table 1). Fireline intensity and fire rate of spread were highly correlated $(\mathrm{r}=0.98, P<0.001)$.

\section{Flame property modeling}

Flame length and fireline intensity were closely linked, and the standard model to relate them, proposed by Byram (1959), fitted the data relatively well (Table 1) although there were a number of noticeable outliers. The relationship that we defined was somewhat different from those produced by previous foundational research (Byram 1959; Thomas 1963) and field studies in similar fuel types (Fig. 3). Flame height was significantly related to the I/U variable, although again, a small number of outliers reduced the overall fit of the model. The model proposed by Taylor (1961) gave a poor fit for flame angle, although the version developed by Albini (1981) performed somewhat better (Table 1). In both cases, the fit of the resulting models was substantially reduced by three outliers (Fig. 3).

\section{Participatory model evaluation}

A total of 64 basic record cards were returned during our participatory data collection period. Most fires reported by managers had moderate ease of ignition (mean: $3.3 \pm 0.7$ ) and moderate difficulty of control (mean: $3.2 \pm 0.9$ ). There was a noisy but significant positive correlation between reported ease of ignition and difficulty of control $(Z=4.46, P$ $<0.001)$ in that fires that were easier to ignite tended to be more difficult to control. Only one fire was reported that would have escaped control if it weren't for the presence of a fire break. Examination of predicted fireline intensity derived from wind speed and fuel height reported on fire record cards revealed a consistent increase in mean predicted intensity with reported control difficulty (Fig. 4). Flame lengths predicted using model 4 (Table 1) showed significant, positive correlations with both reported average $(\mathrm{r}=0.42, P<0.001)$ and maximum 

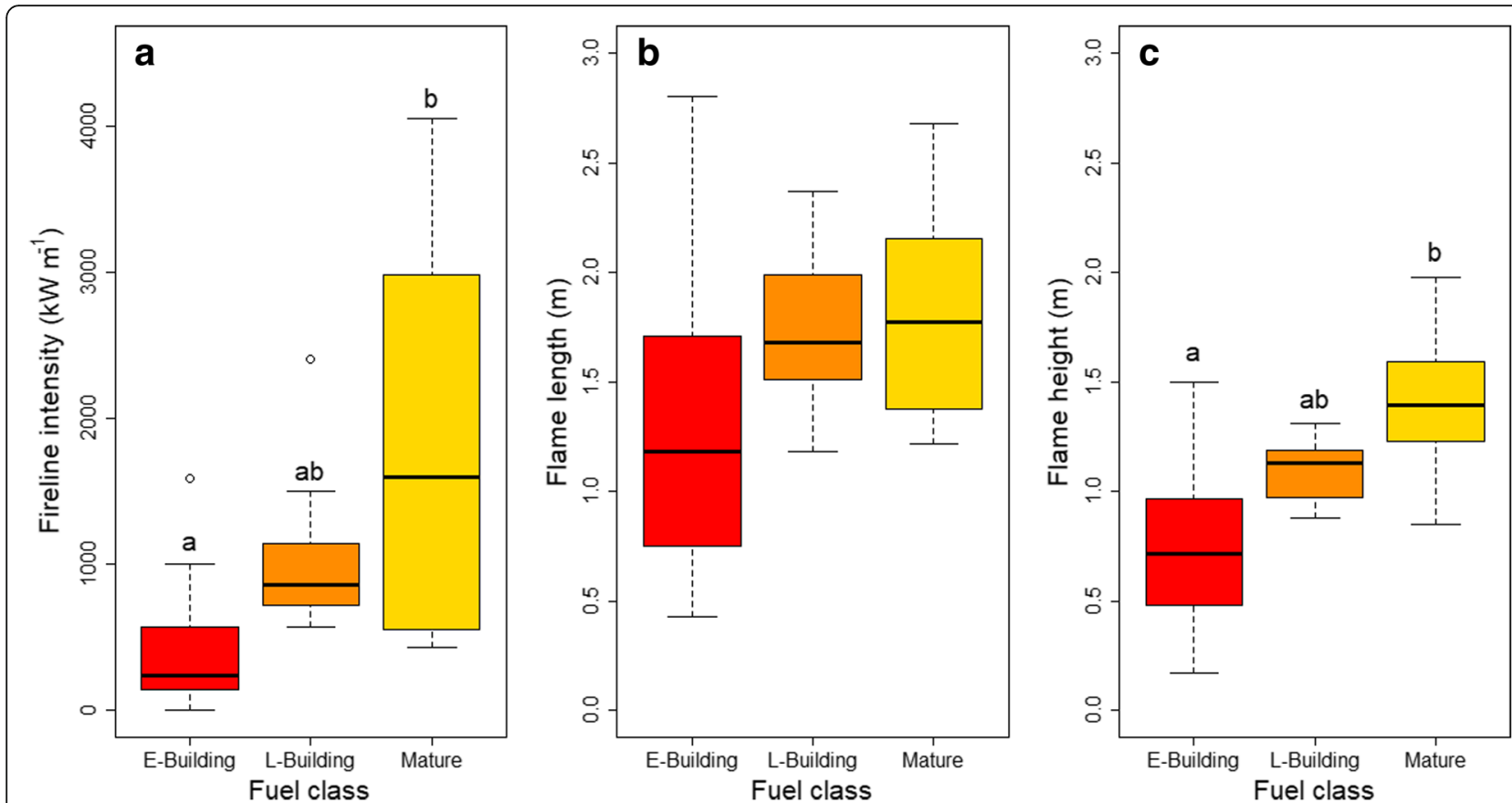

Fig. 2 Variation in (a) fireline intensity, (b) flame length, and (c) flame height in relation to fuel load class for 27 experimental managed burns on Calluna-dominated moorland in Scotland between spring 2006 and autumn 2009. Fuel load classes are phases of the Calluna cycle described by Gimingham (1988): early building phase (E-Building), late-building phase (L-Building) and Mature phase (Mature). The line in the boxplot is the median, the height of the box is defined by the $25^{\text {th }}$ and $75^{\text {th }}$ percentile, and the whiskers represent \pm 2.7 times the standard deviation $(99.3 \%$ of the data). Letters above the boxes show the results of post-hoc pairwise comparisons when boxes with the same letter do not have significantly different means. There was no significant difference by fuel class for flame length

flame length $(\mathrm{r}=0.30, P=0.017)$, although the relationship was somewhat stronger for the latter (Fig. 5). Our model did, however, usually predict higher values of average flame lengths than values estimated by observers.

\section{Discussion}

Developing tools and knowledge to manage fire risk, and safely apply prescribed burning, is a priority in shrubland ecosystems globally (e.g., Fontaine et al. 2012; Fernandes 2013; van Wilgen 2013). The propensity for extreme behavior and threshold changes in the flammability of shrub-dominated fuels poses a particular difficulty. This challenge creates a need for models and guidelines that can be used to estimate potential behavior. Here our aim was to generate empirical models that could be used to support best practice in the application of managed fire, and to evaluate our results using the observations of fires applied by managers on the ground. The participatory approach to model evaluation is a novel aspect of our study and could be more widely adopted to allow large volumes of data to be collected for both managed burns and wildfire behavior. We observed high fire intensities

Table 1 Summary of final regression models for fireline intensity $\left(I ; \mathrm{kW} \mathrm{m}^{-1}\right)$, flame length $(L ; \mathrm{m})$, flame height $(H ; \mathrm{m})$, and flame angle ( $a$; degrees) from 21 experimental fires burned in Calluna-dominated fuels in Scotland between spring 2006 and autumn 2009. Models are based on the predictors fuel height $(h ; m)$, wind speed $\left(U ; \mathrm{m} \mathrm{s}^{-1}\right)$, and live fuel moisture content ( $M_{1}$; percent dry weight), and the gravimetric constant $\left(g=9.8 \mathrm{~m} \mathrm{~s}^{-2}\right)$. The table shows the model form, the coefficients $(\mathrm{a}, \mathrm{b}, \mathrm{or} \mathrm{c})$ for each of the parameters (significance is indicated with $\dagger=P<0.10,{ }^{*}=P<0.05,{ }^{* *}=P<0.01,{ }^{* * *}=P<0.001$ ), and the model's adjusted $\mathrm{R}^{2}$

\begin{tabular}{|c|c|c|c|c|c|}
\hline Model & Form & a & $\mathrm{b}$ & c & $R^{2}$ (adj) \\
\hline 1 & $I=a+b\left(h^{2} U\right)$ & 99.77 & $0.26^{* * *}$ & & 0.58 \\
\hline 2 & $I=a+b\left(h^{2} U\right)+c M_{1}$ & $2449.31^{* *}$ & $0.24^{* * *}$ & $-30.33^{* *}$ & 0.68 \\
\hline 3 & $L=a+b H$ & 0.45 & $1.09^{* *}$ & & 0.42 \\
\hline 4 & $L=a l^{b}$ & $0.22^{* *}$ & $0.29^{* * *}$ & & 0.38 \\
\hline 5 & $H=a+b(I / U)$ & $0.85^{* * *}$ & $0.0009^{* *}$ & & 0.32 \\
\hline 6 & $\tan \left(\mathrm{a}_{\mathrm{a}}\right)=\mathrm{a}\left(U^{3} /\right)^{\mathrm{b}}$ & $1.62^{\dagger}$ & 0.13 & & 0.09 \\
\hline 7 & $\tan \left(\mathrm{a}_{\mathrm{a}}\right)=\mathrm{a}\left(U^{2} / g H\right)^{\mathrm{b}}$ & 1.06 & $0.24^{*}$ & & 0.20 \\
\hline
\end{tabular}



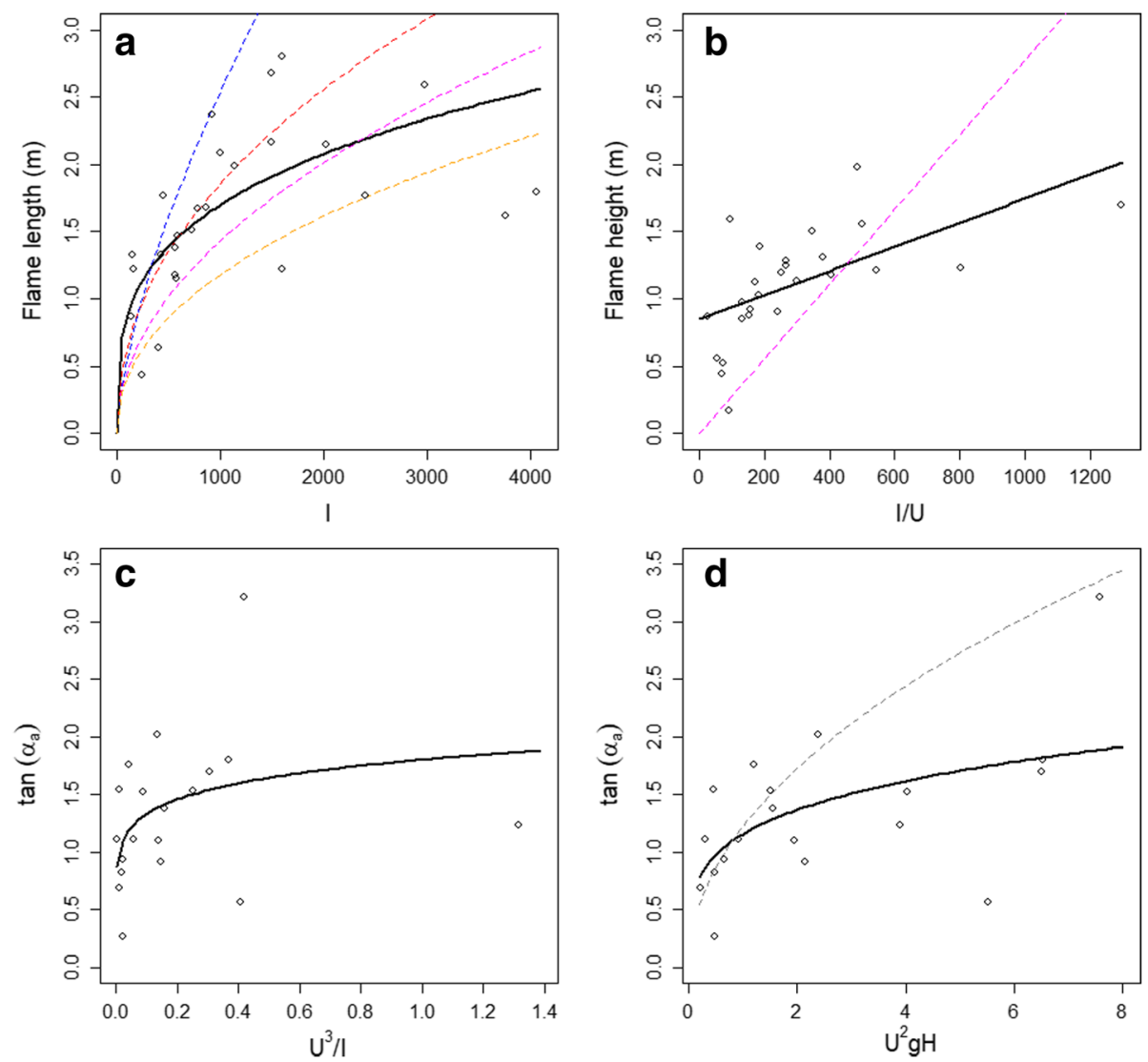

Fig. 3 Predictions from models of flame properties for experimental managed burns on Calluna-dominated moorland in Scotland between spring 2006 and autumn 2009. The figure shows: (a) flame length as a function of fireline intensity $\left(\mathbf{l} ; \mathrm{kW} \mathrm{m}^{-1}\right)$; (b) flame height as a function of fireline intensity divided by wind speed $\left(\mathrm{U} ; \mathrm{m} \mathrm{s}^{-1}\right)$; (c) the tangent of flame angle based on Albini's (1981) proposed model; and (d) the tangent of flame angle (a) based on the model form proposed by Taylor (1961). In all figures, the solid black line represents values predicted by the models in Table 1; other lines report model fits proposed by previous researchers: red = Byram (1959); blue = Thomas (1963); purple = Nelson and Adkins (1986); orange = Fernandes et al. (2000); gray = Albini (1981). Circles represent observed values

despite many of our fires being burned under conditions that might often be considered marginal for sustaining a fire-low temperatures, high humidities, high fuel moistures, and predominantly live fuels (Davies et al. 2009). Even stands with comparatively low fuel loads (i.e., in the "building phase" of the Calluna cycle described by Gimingham (1988)) showed sustaining fire behavior with only one exception. Our spread rates and intensities were comparable to those recorded by Molina and Llinares (1998); De Luis et al. (2004); and Fernandes (2001) in Mediterranean shrubland experimental fires. Our intensity values are, however, around half the highest recorded by Bruce and Servant (2003) in open moorland, where they burned Calluna that was both old and of extremely high loading.

For our fires, fireline intensity was dominated by the effect of rate of spread resulting in a strong linear relationship between the two. This is explained by the substantial differences in the range of rate of spread and mass of fuel consumed-rate of spread varied from $0.5 \mathrm{~m} \mathrm{~min}^{-1}$ to 12.6 $\mathrm{m} \min ^{-1}$ (Davies et al. 2009), while fuel consumption ranged from $0.5 \mathrm{~kg} \mathrm{~m}^{-2}$ to $1.2 \mathrm{~kg} \mathrm{~m}^{-2}$ (Davies et al. 2016b). It was thus unsurprising that model structures that have previously been shown to predict rate of spread worked well for our fireline intensity data. A number of previous authors (e.g., Fernandes 2001; Anderson et al. 2015) have also developed empirical models of fire spread in shrub fuels as a function of fuel height and wind speed. Although the specific details of the equations vary between studies, the results are consistent in broad terms: rate of spread and intensity increase as a function of fuel height and wind speed. Vegetation height is important as it is not only correlated with total fuel and fine fuel loading but also with bulk density. Bulk density is known to be negatively correlated with fire reaction intensity (Drysdale 2011); in taller Calluna, vegetation bulk density is reduced as the canopy is lifted off the ground by growing stems. A higher canopy is therefore likely to be more entrained by the atmosphere 


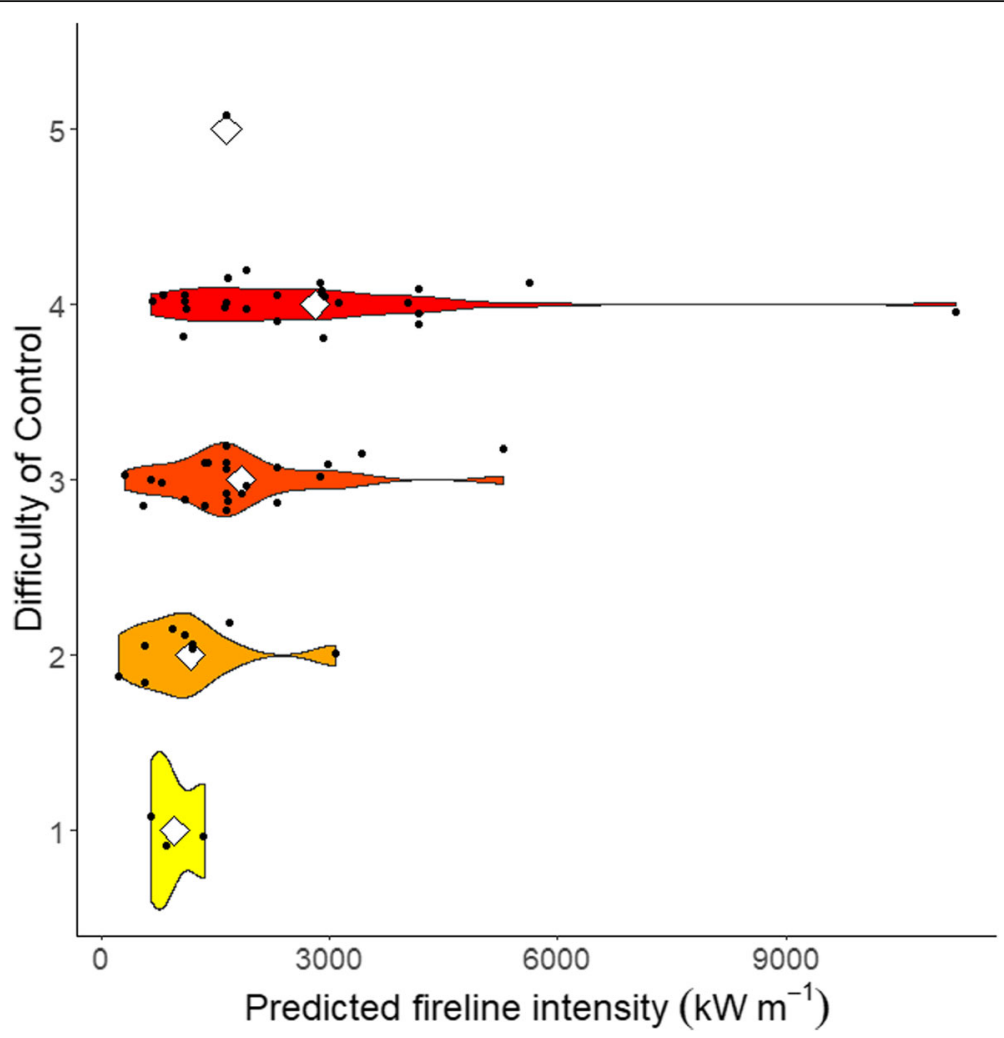

Fig. 4 Strip and violin plot showing predicted fireline intensity of experimental managed burns on Calluna-dominated moorland in Scotland, between spring 2006 and autumn 2009, based on Equation 1 (Table 1) in relation to difficulty of control reported by land managers using basic record cards (see Additional file 1). Fireline intensity was estimated on the basis of manager-reported Beaufort wind speed and Calluna stand height. Data points are jittered on the vertical axis for clarity
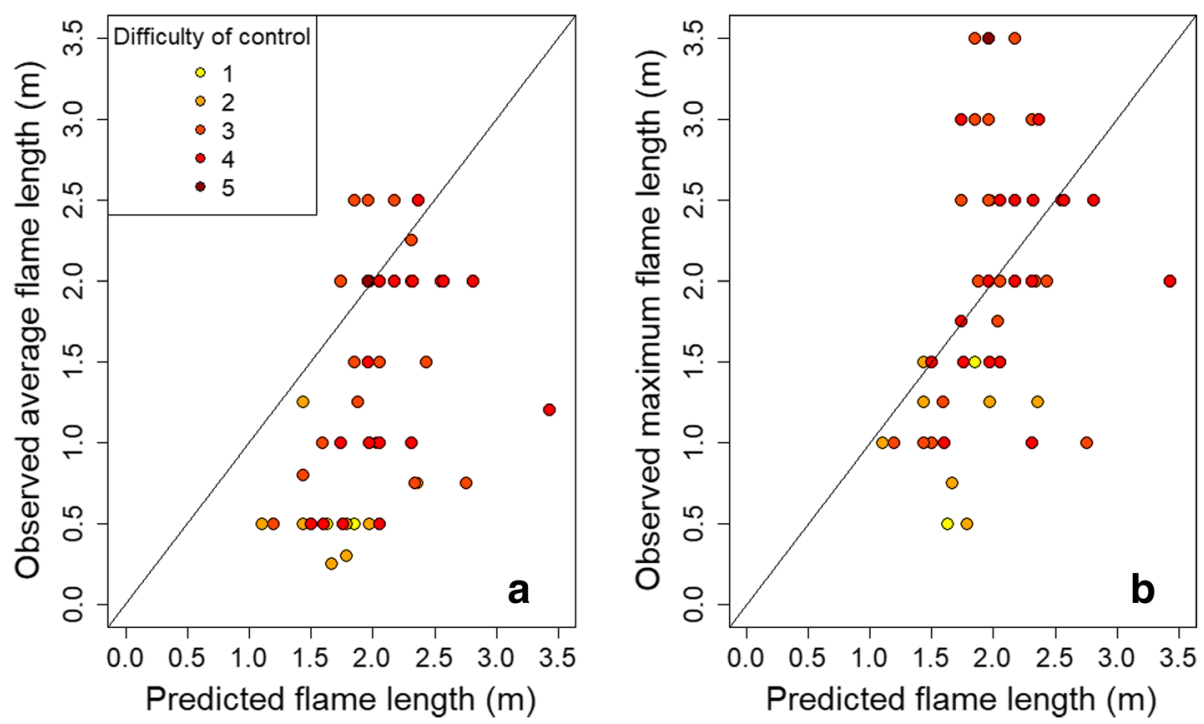

Fig. 5 Relationship between predicted flame length and average (a) and maximum (b) flame length reported by stakeholders using managed fire reporting cards for experimental managed burns on Calluna-dominated moorland in Scotland between spring 2006 and autumn 2009 . The 1:1 relationship is shown as a diagonal black line. Point color refers to reported difficulty of fire control, with darker colors indicating more challenging burns. Predictions of flame length were based on Equations 1 and 4 (Table 1), and observations of fuel height and wind speed were made by stakeholders during fires that they burned 
and less likely to suffer from oxygen deprivation. The latter can sometimes be patchily and ephemerally observed in burning dwarf-shrub canopies close to the ground. However, taller, older Calluna stands also tend to have a more patchy structure, and canopy gaps often develop (Davies et al. 2008). More patchy but lower-density fuels in mature Calluna stands make the response to wind speed much greater in those fuels than in more uniform, denser building phase canopies where fire spreads even in low wind speeds.

Shrubland fires are often considered to be akin to mini independent crown fires (e.g., Alexander and Sando 1989; Fernandes et al. 2000), where fire can spread through shrub canopies irrespective of the flammability of ground fuels (layers of moss and litter). This observation points to a limitation in our results: for safety reasons, all of our burns were completed during the spring when ground fuels were too wet to burn. In drier conditions, when these fuels dry below the threshold of ignition, they can double the available fuel load and significantly alter fire behavior. Further test fires in a wider range of conditions are therefore required.

An unusual aspect of the structure of many shrubland fuel types, including Calluna, is that they are dominated by live fuel components. The apparently unusual behavior of shrub fires has been ascribed to the fact that, until recently, live fuels were treated as "very moist dead fuels" (Finney et al. 2013), ignoring their unique chemical, physical, and physiological characteristics (Jolly and Johnson 2018). Thus, while it is generally accepted that higher moisture contents dampen fire intensity and spread rate (Catchpole and Catchpole 1991; Baeza et al. 2002), live fuels can nevertheless burn at moisture contents that would be considered too high for dead fuels to ignite. Live fuel moisture content has been shown to be important in determining thresholds for ignition and fire activity in other shrubland ecosystems (Chuvieco et al. 2009; Dennison and Moritz 2009; Weise et al. 2016), and Calluna is unusual in its very low live fuel moisture content that can occur during early spring (Davies et al. 2010). Our results noted a significant effect of live fuel moisture content on fireline intensity with higher moisture contents associated with reduced fire intensity. This suggests that developing models (e.g., Pellizzaro et al. 2007; Dennison et al. 2008), or using remote sensing to estimate live fuel moisture (Riano et al. 2005; Caccamo et al. 2011), would be useful for assessing fire potential in Calluna-dominated fuels.

We were able to build statistically significant but noisy models of flame properties on the basis of well established, physically based formulations for developing empirical relationships with fire intensity. The fairly substantial scatter in our data was at least in part a result of the difficulty of making accurate flame observations for fast-moving, intense, smoky burns. Gusty wind conditions added to the difficulty, and future fire monitoring would ideally involve digital video footage of the fires in addition to the visual observation and still photos that we were able to use. The outliers for some of our fires were generally explained by fires for which variable wind speed and direction led to more dynamic and variable flame fronts. Our results generally agreed well with those found by previous researchers, although again, the specific relationships were slightly different from those seen in other shrubland fuel types (e.g., Anderson et al. 2006; Fernandes et al. 2018).

Our basic record card data proved useful in evaluating our empirical fire behavior models and suggested that they performed tolerably well. Data on the record cards was collected from a wide variety of settings and included managed burns in Caldeonian pinewoods, lowland dry heaths, moorland, and blanket peatlands. Sites were scattered from northern Scotland to southern England. The common factor in all of these settings was that Calluna formed the dominant component of the fuel bed. This variation, along with the relatively simple manner and low resolution with which data were collected, explains the extent of the scatter in the relationship between predicted and observed fire behavior characteristics. Given this, it is somewhat remarkable that the relationships were as strong as we observed and our findings suggested that our models could be adopted to provide managers with a useful indication of potential fire behavior. If remotely sensed data on live fuel moisture content were to become available (e.g., Caccamo et al. 2011), the predictive ability of our models would be improved further as the results presented here are based solely on fuel height and visually estimated wind speed. Our stakeholder data added to existing evidence (Allen et al. 2016) that many prescribed fires are competently managed and follow current recommended guidelines for planning and implementation. The relationships we presented here can be developed into a simple nomogram to improve prescribed burning training and planning (Fig. 6).

\section{Conclusions}

Prescribed fire can be used to achieve a multitude of ecological outcomes, and this includes maintaining the diversity, structure, and function of internationally important heathland and moorland ecosystems (Davies et al. 2008). While there is considerable ongoing debate about the role and effects of fire in the management of Calluna-dominated ecosystems in the British uplands, it is in the interests of all land managers and conservationists to ensure that burns are completed as safely as possible. The fire behavior aspects that we have characterized all play a significant role in determining the extent to which managed burning operations can be completed safely and 

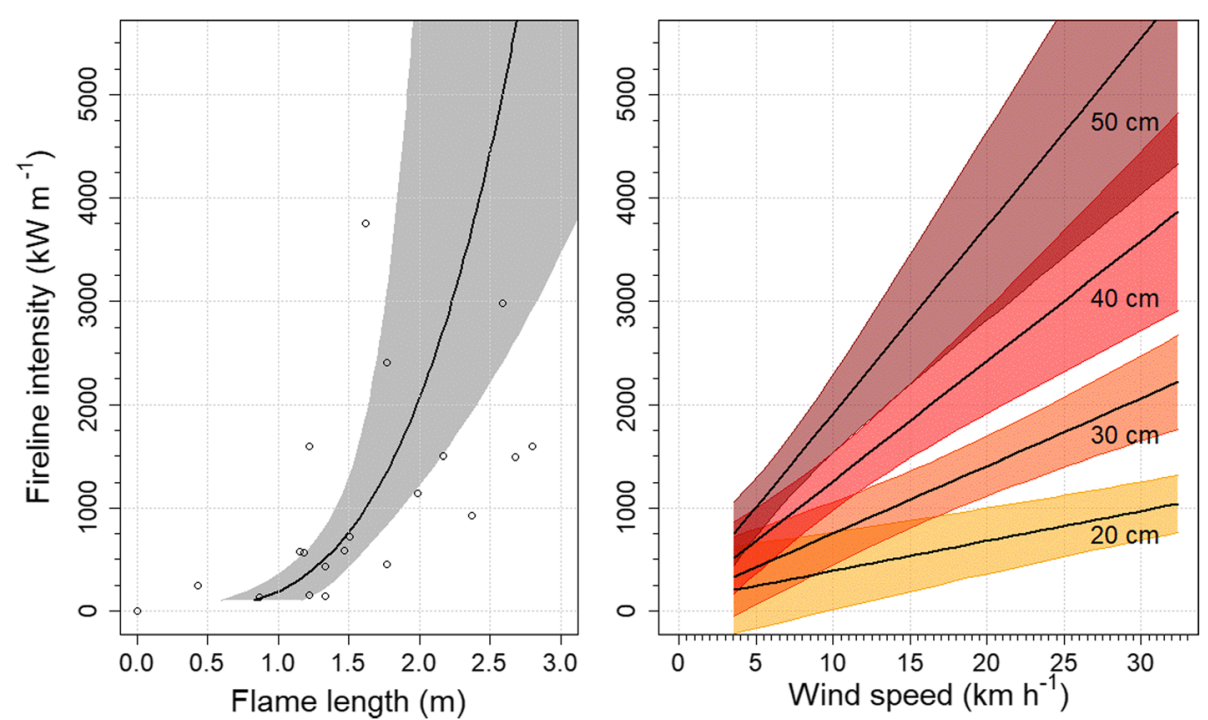

Fig. 6 A fire behavior nomogram based on predictions from Equations 1 and 4 (Table 1). Right: fireline intensity is predicted as a function of wind speed for four different fuel heights. Left: flame length can be predicted from the estimated fireline intensity - the figure is organized so that the predicted intensity can be read across to predict flame length. Black lines show the predicted values, shaded areas around the lines demarcate the $95 \%$ confidence interval of the modeled fireline intensity or flame length. Observed flame lengths and intensities, from experimental managed burns on Calluna-dominated moorland in Scotland between spring 2006 and autumn 2009, are shown as circles.

effectively. A variety of static, dynamic, and spatial tools exist to model fire behavior (e.g., Papadopoulos and Pavlidou 2011), yet we still lack a complete, fundamental understanding (Finney et al. 2013). The models that we have developed use the best available evidence for managed burns in Calluna-dominated fuels and we recommend that, with caution and acknowledging the large degree of uncertainty for flame length predictions in particular, they can be used to provide indicative estimates of potential fire behavior.

\section{Additional file}

Additional file 1: Example of completed record cards used in participatory collection of data on fire behavior. (DOCX $409 \mathrm{~kb}$ )

\section{Authors' contributions}

GMD designed the experiment, completed the fieldwork, analyzed the data, and wrote the manuscript; CJL contributed to designing the experiment, reviewed the data analysis, and helped write the manuscript; AAS contributed to designing the experiment, assisted with fieldwork, and helped write the manuscript; AM reviewed the data analysis and helped write the manuscript. All authors read and approved the final manuscript.

\section{Funding}

Funding for this research was provided by the Natural Environment Research Council (Ref: NER/S/C/2001/06470), the Game and Wildlife Conservation

Trust, Scottish Natural Heritage, and the Scottish Government through the Scottish Wildfire Forum.

\section{Availability of data and materials}

All data and scripts used in this manuscript are available in the associated Additional file 1.

Ethics approval and consent to participate

Not applicable.

\section{Consent for publication}

Not applicable.

Estate for allowing us to use their land for our experimental burns. S. Newey, D. Howarth, A. Kirby, H. Robertson, C. Smithard, I. Graham, E. Watts, E. Steele, B. Higham, T. Valor Ivars, and E. Boyd assisted in managing the burns and recording fire behavior. A number of individuals contributed their time and expertise to generate basic record data for fires that they managed; our particular thanks to: M. Bruce (Glen Tanar Estate), D. Dugan (Royal Society for the Protection of Birds), and D. Morris (Forestry Commission). Some laptops were harmed during the course of this study. M. Bruce and W. Anderson provided useful comments and suggestions on early versions of this research. This paper is dedicated to the memory of Professor Charles Gimingham (1923 to 2018), the doyen of British fire and heathland ecology. It is testament to his legacy that he was the academic grandfather or father to two of the authors of this paper and an academic father, grandfather, or great-grandfather to five other authors whose work is cited here.

\section{Competing interests}

The authors declare that they have no competing interests.

\section{Author details}

${ }^{1}$ The Ohio State University, School of Environment and Natural Resources, Kottman Hall, 2021 Coffey Road, Columbus, Ohio 43210, USA. ${ }^{2}$ The University of Edinburgh, School of GeoSciences, Crew Building, The King's Buildings, Alexander Crum Brown Road, Edinburgh EH9 3FF, Scotland. ${ }^{3}$ The Game and Wildlife Conservation Trust, Drumochter Lodge, Dalwhinnie, Inverness-shire PH19 1AF, Scotland. ${ }^{4}$ Scottish Natural Heritage (retired), 18/1 Cowan Road, Edinburgh EH11 1RQ, Scotland. 
Received: 5 September 2018 Accepted: 17 June 2019 Published online: 19 August 2019

\section{References}

Albini, F.A. 1981. A model for the wind-blown flame from a line fire. Combustion and Flame 43: 155-174 https://doi.org/10.1016/0010-2180(81)90014-6.

Albini, F.A., M.E. Alexander, and M.G. Cruz. 2012. A mathematical model for predicting the maximum potential spotting distance from a crown fire. International Journal of Wildland Fire 21: 609-627 https://doi.org/10.1071/WF11020.

Alexander, M.E., and M.G. Cruz. 2011. Interdependencies between flame length and fireline intensity in predicting crown fire initiation and crown scorch height. International Journal of Wildland Fire 21: 95-113 https://doi.org/10. 1071/WF11001.

Alexander, M.M.E., and R.W. Sando. 1989. Fire behavior and effects in aspennorthern hardwood stands. In Proceedings of the 10th conference on fire and forest meteorology, 17-21 April 1989, Ottawa, Ontario, ed. D.C. Maclver, H. Auld, and R. Whitewood, 263-274.. Ottawa: Canadian Forest Service and Environment Canada.

Allen, K.A., P. Denelle, F.M. Sánchez Ruiz, V.M. Santana, and R.H. Marrs. 2016. Prescribed moorland burning meets good practice guidelines: a monitoring case study using aerial photography in the Peak District, UK. Ecological Indicators 62: 76-85 https://doi.org/10.1016/j.ecolind.2015.11.030.

Allen, K.A., M.P. Harris, R.H. Marrs, and P. Kardol. 2013. Matrix modelling of prescribed burning in Calluna vulgaris-dominated moorland: short burning rotations minimize carbon loss at increased wildfire frequencies. Journal of Applied Ecology 50: 614-624 https://doi.org/10.1111/1365-2664.12075.

Anderson, W.R., M.G. Cruz, P.M. Fernandes, L. McCaw, J.A. Vega, R.A. Bradstock, L. Fogarty, J. Gould, G. McCarthy, J.B. Marsden-Smedley, S. Matthews, G. Mattingley, G.H. Pearce, and B.W. van Wilgen. 2015. A generic, empiricalbased model for predicting rate of fire spread in shrublands. International Journal of Wildland Fire 24: 443-460 https://doi.org/10.1071/WF14130.

Anderson, W.R., E. Pastor, B. Butler, E. Catchpole, P. Fernandes, M. Guijarro, J.-M. Mendes-Lopes, and J. Ventura. 2006. Evaluating models to estimate flame characteristics for free-burning fires using laboratory and field data. Forest Ecology and Management 234 (Supplement): s77 https://doi.org/10.1016/j. foreco.2006.08.113.

Ascoli, D, Bovio, G, 2013. Prescribed burning in Italy: issues, advances and challenges. iForest 6: 79-89 [online 2013-02-07]. http://www.sisef.it/iforest/ contents?id=ifor0803-005.

Baeza, M.J., M. De Luís, J. Raventós, and A. Escarré. 2002. Factors influencing fire behaviour in shrublands of different stand ages and the implications for using prescribed burning to reduce wildfire risk. Journal of Environmental Management 65: 199-208 https://doi.org/10.1006/jema.2002.0545.

Bilgili, E., and B. Saglam. 2003. Fire behaviour in maquis fuels in Turkey. Forest Ecology and Management 184: 201-207 https://doi.org/10.1016/S03781127(03)00208-1.

Brockett, B.H., H.C. Biggs, and B.W. van Wilgen. 2001. A patch mosaic burning system for conservation areas in southern African savannas. International Journal of Wildland Fire 10: 169-183 https://doi.org/10.1071/WF01024.

Brown, J.K., and C.D. Bevins. 1986. Surface fuel loadings and predicted fire behavior for vegetation types in the Northern Rocky Mountains. USDA Forest Service Research Note INT-358. Ogden: USDA Forest Service, Intermountain Research Station.

Brown, L.E., K. Johnston, S.M. Palmer, K.L. Aspray, and J. Holden. 2013. River ecosystem response to prescribed vegetation burning on blanket peatland. PLOS ONE 8: e81023 https://doi.org/10.1371/journal.pone.0081023.

Bruce, M.A., and G. Servant. 2003. Fire and pinewood ecology in Scotland: a summary of recent research at Glen Tanar Estate, Aberdeenshire. Scottish Forestry 57: 33-38.

Burrows, N., and L. McCaw. 2013. Prescribed burning in southwestern Australian forests. Frontiers in Ecology and the Environment 11: e25-e34 https://doi.org/ 10.1890/120356.

Byram, G.M. 1959. Combustion of forest fuels. In Forest fire: control and use, ed. K. P. Davis, 61-89. New York: McGraw-Hill.

Caccamo, G., L.A. Chisholm, R.A. Bradstock, M.L. Puotinen, and B.G. Pippen. 2011 Monitoring live fuel moisture content of heathland, shrubland and sclerophyll forest in south-eastern Australia using MODIS data. International Journal of Wildland Fire 21: 257-269 https://doi.org/10.1071/WF11024.

Catchpole, E.A., and W.R. Catchpole. 1991. Modelling moisture damping for fire spread in a mixture of live and dead fuels. International Journal of Wildland Fire 1: 101-106 https://doi.org/10.1071/WF9910101.
Catchpole, W.R., R. Bradstock, J. Choate, L. Fogarty, N. Gellie, G. McCarthy, L. McCaw, J. Marsden-Smedley, and G. Pearce. 1998. Cooperative development of equations for heathland fire behaviour. In Proceedings of the III international conference on forest fire research and the $14^{\text {th }}$ conference on fire and forest meteorology. Volume I. Luso, Coimbra, Portugal 16-20 November 1998, ed. by D.X. Viegas, 631-645. Coimbra: ADAI.

Cheney, N.P., J.S. Gould, and W.R. Catchpole. 1993. The influence of fuel, weather and fire shape variables on fire-spread in grasslands. International Journal of Wildland Fire 3: 31-44 https://doi.org/10.1071/WF9930031.

Chuvieco, E., I. González, F. Verdú, I. Aguado, and M. Yebra. 2009. Prediction of fire occurrence from live fuel moisture content measurements in a Mediterranean ecosystem. International Journal of Wildland Fire 18: 430-441 https://doi.org/10.1071/WF08020.

R Core Team. 2018. R: a language and environment for statistical computing. Vienna: R Foundation for Statistical Computing https://www.R-project.org/.

Davies, G.M. 2006. Fire behaviour and impact on heather moorlands. Thesis. Scotland: University of Edinburgh.

Davies, G.M., R. Domènech, A. Gray, and P.C.D. Johnson. 2016b. Vegetation structure and fire weather influence variation in burn severity and fuel consumption during peatland wildfires. Biogeosciences 13: 389-398 https:// doi.org/10.5194/bg-13-389-2016

Davies, G.M., A. Gray, A. Hamilton, and C.J. Legg. 2008. The future of fire management in the British uplands. International Journal of Biodiversity Science \& Management 4: 127-147 https://doi.org/10.3843/Biodiv.4.3:1.

Davies, G.M., N. Kettridge, C.R. Stoof, A. Gray, D. Ascoli, P.M. Fernandes, R. Marrs, K. A. Allen, S.H. Doerr, G. Clay, J. McMorrow, and V. Vandvik. 2016a. The role of fire in U.K. peatland and moorland management; the need for informed, unbiased debate. Philosophical Transactions of the Royal Society B 371: 20150342 https://doi.org/10.1098/rstb.2015.0342.

Davies, G.M., and C.J. Legg. 2016. Regional variation in fire weather controls the occurrence of Scottish wildfires. PeerJ 4: e2649 https://doi.org/10. 7717/peerj.2649.

Davies, G.M., C.J. Legg, A.A. Smith, and A.J. McDonald. 2009. Rate of spread of fires in Calluna vulgaris-dominated moorlands. Journal of Applied Ecology 46: 1054-1063 https://doi.org/10.1111/j.1365-2664.2009.01681.x.

Davies, G.M., R. O'Hara, A.A. Smith, A. MacDonald, and C.J. Legg. 2010. Winter desiccation and rapid changes in the live fuel moisture content of Calluna vulgaris. Plant Ecology \& Diversity 3: 289-299 https://doi.org/10.1080/ 17550874.2010 .544335$.

de Jong, M.C., M.J. Wooster, K. Kitchen, C. Manley, R. Gazzard, and F.F. McCall. 2016. Calibration and evaluation of the Canadian Forest Fire Weather Index (FWI) system for improved wildland fire danger rating in the United Kingdom. Natural Hazards and Earth Systems Sciences 16: 1217-1237 https:// doi.org/10.5194/nhess-16-1217-2016.

De Luis, M., M.J. Baeza, J. Raventos, and J.C.G. Gonzalez-Hidalgo. 2004. Fuel characteristics and fire behaviour in mature Mediterranean gorse shrublands. International Journal of Wildland Fire 13: 79-87 https://doi.org/10.1071/WF03005.

Dennison, P.E., and M. Moritz. 2009. Critical live fuel moisture in chaparral ecosystems: a threshold for fire activity and its relationship to antecedent precipitation. International Journal of Wildland Fire 18: 1021-1027 https://doi. org/10.1071/WF08055.

Dennison, P.E., M.A. Moritz, and R.S. Taylor. 2008. Evaluating predictive models of critical live fuel moisture in the Santa Monica Mountains, California. International Journal of Wildland Fire 17: 18-27 https://doi.org/10.1071MF07017.

Dickinson, J.L., B. Zuckerberg, and D.N. Bonter. 2010. Citizen science as an ecological research tool: challenges and benefits. Annual Review of Ecology, Evolution, and Systematics 41: 149-172 https://doi.org/10.1146/annurev-ecolsys-102209-144636.

Drysdale, D. 2011. An introduction to fire dynamics. 3rd edition. New York: Wiley https://doi.org/10.1002/9781119975465.

Espinosa, J., P. Palheiro, C. Loureiro, D. Ascoli, A. Esposito, and P.M. Fernandes. 2019. Fire severity mitigation by prescribed burning assessed from fire-treatment encounters in maritime pine stands. Canadian Journal of Forest Research 49: 205-211 https://doi.org/10. 1139/cjfr-2018-0263.

Fagúndez, J. 2013. Heathlands confronting global change: drivers of biodiversity loss from past to future scenarios. Annals of Botany 111: 151-172 https://doi. org/10.1093/aob/mcs257.

Fernandes, P., H. Botelho, and C. Loureiro. 2002. Models for the sustained ignition and behaviour of low-to-moderately intense fires in maritime pine stands. In IV International Conference on Forest Fire Research/2002 Wildland Fire Safety Summit. 18-20 November, 2002, Luso, Portugal. Rotterdam: Millpress. 
Fernandes, P.M. 2001. Fire spread prediction in shrub fuels in Portugal. Forest Ecology and Management 144: 67-74 https://doi.org/10.1016/S0378-1127(00)00363-7.

Fernandes, P.M. 2013. Fire-smart management of forest landscapes in the Mediterranean basin under global change. Landscape Urban Plan 110: 175-182 https://doi.org/10.1016/j.landurbplan.2012.10.014.

Fernandes, P.M., and H.S. Botelho. 2003. A review of prescribed burning effectiveness in fire hazard reduction. International Journal of Wildland Fire 12: 117-128 https://doi.org/10.1071/WF02042.

Fernandes, P.M., W.R. Catchpole, and F.C. Rego. 2000. Shrubland fire behaviour modelling with microplot data. Canadian Journal of Forest Research 30: 889899 https://doi.org/10.1139/x00-012.

Fernandes, P.M., G.M. Davies, D. Ascoli, C. Fernández, F. Moreira, E. Rigolot, C.R. Stoof, J.A. Vega, and D. Molina. 2013. Prescribed burning in southern Europe: developing fire management in a dynamic landscape. Frontiers in Ecology and the Environment 11: e4-e14 https://doi.org/10.1890/120298.

Fernandes, P.M., Â. Sil, D. Ascoli, M.G. Cruz, M.E. Alexander, C.G. Rossa, J. Baeza, N. Burrows, G.M. Davies, A. Fidelis, J.M. Gould, N. Govender, M. Kilinc, and L. McCaw. 2018. Drivers of wildland fire behaviour variation across the Earth. In Advances in forest fire research, ed. D.X. Viegas, 1267-1270. Coimbra: Imprensa da Universidade de Coimbra.

Finney, M.A., J.D. Cohen, S.S. McAllister, and W.M. Jolly. 2013. On the need for a theory of wildland fire spread. International Journal of Wildland Fire 22: 25-36 https://doi.org/10.1071/WF11117.

Fontaine, J.B., V.C. Westcott, N.J. Enright, J.C. Lade, and B.P. Miller. 2012. Fire behaviour in south-western Australian shrublands: evaluating the influence of fuel age and fire weather. International Journal of Wildland Fire 21: 385395 https://doi.org/10.1071/WF11065.

Gimingham, C. 1988. A reappraisal of cyclical processes in Calluna heath. Vegetatio 77: 61-64 https://doi.org/10.1007/BF00045751.

Grau, R., G.M. Davies, S. Waldron, M. Scott, and A. Gray. 2017. Leaving moss and litter layers undisturbed reduces the short-term environmental consequences of heathland managed burns. Journal of Environmental Management 204: 102-110 https://doi.org/10.1016/j.jenvman.2017.08.017.

Grau-Andrés, R., A. Gray, and G.M. Davies. 2017. Sphagnum abundance and photosynthetic capacity show rapid short-term recovery following managed burning. Plant Ecology \& Diversity 10: 353-359 https://doi.org/10.1080/ 17550874.2017.1394394.

Hirsch, K.G., and D.L. Martell. 1996. A review of initial attack fire crew productivity and effectiveness. International Journal of Wildland Fire 6: 199-215 https://doi. org/10.1071/WF9960199.

Hobbs, R., and C. Gimingham. 1984. Studies on fire in Scottish heathland communities: I. fire characteristics. Journal of Ecology 72: 223-240 https://doi. org/10.2307/2260015

Hobbs, R.J. 1981. Post-fire succession in heathland communities. Thesis. Scotland: University of Aberdeen.

Holden, J., P.J. Chapman, S.M. Palmer, P. Kay, and R. Grayson. 2012. The impacts of prescribed moorland burning on water colour and dissolved organic carbon: a critical synthesis. Journal of Environmental Management 101: 92-103 https://doi. org/10.1016/j.jenvman.2012.02.002.

Jolly, W.M., and D.M. Johnson. 2018. Pyro-ecophysiology: shifting the paradigm of live wildland fuel research. Fire 1: 8 https://doi.org/10.3390/fire1010008.

Log, T., Thuestad, G., Velle, L., Khattri, S. \& Kleppe, G. 2017. Unmanaged heathland - A fire risk in subzero temperatures? Fire Safety Journal. 90. 62-71 https://doi. org/10.1016/j.firesaf.2017.04.017.

Lumley, T., and A. Miller. 2017. leaps: regression subset selection. R package version 3.0. https://CRAN.R-project.org/package=leaps Accessed 6 June 2019.

Maltby, E., C. Legg, and M. Proctor. 1990. The ecology of severe moorland fire on the North York Moors: effects of the 1976 fires, and subsequent surface and vegetation development. Journal of Ecology 78: 490-518 https://doi.org/10.2307/2261126.

Molina, M.J., and J.V. Llinares. 1998. Relationships between fire behaviour, weather conditions and fire intensity parameters in experimental summer fires in Valencia shrublands. In Proceedings of the III international conference on forest fire research and the 14th conference on fire and forest meteorology. Volume I. Luso, Coimbra, Portugal 16-20 November 1998, edited by D.X. Viegas, pages 661-676. Coimbra: ADAl.

Moreira, F., O. Viedma, M. Arianoutsou, T. Curt, N. Koutsias, E. Rigolot, A. Barbati, P. Corona, P. Vaz, G. Xanthopoulos, F. Mouillot, and E. Bilgili. 2011. Landscapewildfire interactions in southern Europe: implications for landscape management. Journal of Environmental Management 92: 2389-2402 https:// doi.org/10.1016/j.jenvman.2011.06.028.

Morvan, D., V. Tauleigne, and J.L. Dupuy. 2002. Wind effects on wildfire propagation through a Mediterranean shrub. In Proceedings of the $\mathrm{N}$ international conference on forest fire research and the 2002 wildland fire safety summit, ed. D.X. Viegas. Luso, Coimbra, Rotterdam: Millpress.

Nelson, R.M., Jr., and C.A. Adkins. 1986. Flame characteristics of wind-driven surface fires. Canadian Journal of Forest Research 16 (1): 293-1300 https://doi. org/10.1139/x86-229.

Noble, A., S.M. Palmer, D.J. Glaves, A. Crowle, L.E. Brown, and J. Holden. 2018 Prescribed burning, atmospheric pollution and grazing effects on peatland vegetation composition. Journal of Applied Ecology 55: 559-569 https://doi. org/10.1111/1365-2664.12994.

Papadopoulos, G.D., and F. Pavlidou. 2011. A comparative review on wildfire simulators. IEEE Systems Journal 5 (2): 233-243 https://doi.org/10.1109/JSYST. 2011.2125230.

Pearce-Higgins, J.W., and M.C. Grant. 2006. Relationships between bird abundance and the composition and structure of moorland vegetation. Bird Study 53: 112-125 https://doi.org/10.1080/00063650609461424.

Pellizzaro, G., C. Cesaraccio, P. Duce, A. Ventura, and P. Zara. 2007. Relationships between seasonal patterns of live fuel moisture and meteorological drought indices for Mediterranean shrubland species. International Journal of Wildland Fire 16: 232-241 https://doi.org/10.1071/WF06081.

Peters, G. 2018. userfriendlyscience: quantitative analysis made accessible. R package version 0.7.1. https://userfriendlyscience.com Accessed 6 June 2019.

Pompe, A., and R.G. Vines. 1966. The influence of moisture on the combustion of leaves. Australian Forestry 30: 231-241 https://doi.org/10.1080/00049158.1966. 10675417.

Riano, D., P. Vaughan, E. Chuvieco, P.J. Zarco-Tejada, and S.L. Ustin. 2005. Estimation of fuel moisture content by inversion of radiative transfer models to simulate equivalent water thickness and dry matter content: analysis at leaf and canopy level. IEEE Transactions on Geoscience and Remote Sensing 43 819-826 https://doi.org/10.1109/TGRS.2005.843316.

Robertson, G.S., D. Newborn, M. Richardson, and D. Baines. 2017. Does rotational heather burning increase red grouse abundance and breeding success on moors in northern England? Wildlife Biology https://doi.org/10.2981/wlb.00227.

Rodwell, J.S., editor. 1991. British Plant Communities. Volume 2. Mires and heath. Cambridge: Cambridge University Press.

Santana, V.M., J.G. Alday, H. Lee, K.A. Allen, and R.H. Marrs. 2016. Modelling carbon emissions in Calluna vulgaris-dominated ecosystems when prescribed burning and wildfires interact. PLOS ONE 11: e0167137 https://doi.org/10. 1371/journal.pone.0167137.

Sullivan, A.L. 2009. Wildland surface fire spread modelling, 1990-2007. 2: empirical and quasi-empirical models. International Journal of Wildland Fire 18: 369-386 https://doi.org/10.1071/WF06142.

Sylvester, T.W., and R.W. Wein. 1981. Fuel characteristics of Arctic plant species and simulated plant community flammability by Rothermel's model. Canadian Journal of Botany 59: 898-907 https://doi.org/10.1139/b81-125.

Taylor, E.S., P.E. Levy, and A. Gray. 2017. The recovery of Sphagnum capillifolium following exposure to temperatures of simulated moorland fires: a glasshouse experiment. Plant Ecology \& Diversity 10: 77-88 https://doi.org/10. 1080/17550874.2017.1302017.

Taylor, G.I. 1961. Fire under influence of natural convection. In The uses of models in fire research. Publication 786, ed. W.G. Berl, 10-31. Washington, D.C.: National Academy of Sciences, National Research Council.

Thomas, H. 1963. The size of flames from natural fires. Symposium (International) on Combustion 9 (1): 844-859 https://doi.org/10.1016/S0082-0784(63)80091-0.

Thompson, D.B.A., A.J. MacDonald, J.H. Marsden, and C.A. Galbraith. 1995. Upland heather moorland in Great Britain: a review of international importance, vegetation change and some objectives for nature conservation. Biological Conservation 71: 163-178 https://doi.org/10.1016/0006-3207(94)00043-P.

Vandvik, V., Töpper, J. P., Cook, Z., Daws, M. I., Heegaard, E., Måren, I. E., \& Velle, L. G. 2014. Management-driven evolution in a domesticated ecosystem. Biology letters, 10(2), 20131082 https://doi.org/10.1098/rsbl.2013.1082.

van Mantgem, P.J., L.B. Lalemand, M. Keifer, and J.M. Kane. 2016. Duration of fuels reduction following prescribed fire in coniferous forests of US national parks in California and the Colorado Plateau. Forest Ecology and Management 379: 265-272 https://doi.org/10.1016/j.foreco.2016.07.028.

Van Wagner, C.E. 1973. Height of crown scorch in forest fires. Canadian Journal of Forest Research 3: 373-378 https://doi.org/10.1139/x73-055.

van Wilgen, B.W. 2013. Fire management in species-rich Cape fynbos shrublands. Frontiers in Ecology and the Environment 11: e35-e44 https://doi.org/10.1890/ 120137.

Ward, S.E., R.D. Bardgett, N.P. McNamara, J.K. Adamson, and N.J. Ostle. 2007. Long-term consequences of grazing and burning on northern peatland 
carbon dynamics. Ecosystems 10: 1069-1083 https://doi.org/10.1007/s10021007-9080-5.

Weise, D.R., E. Koo, X. Zhou, S. Mahalingam, F. Morandini, and J.-H. Balbi. 2016. Fire spread in chaparral-a comparison of laboratory data and model

predictions in burning live fuels. International Journal of Wildland Fire 25:980994 https://doi.org/10.1071/WF15177.

Wilson, A.A.G. 1988. Width of firebreak that is necessary to stop grass fires: some field experiments. Canadian Journal of Forest Research 18: 682-687 https:// doi.org/10.1139/×88-104.

\section{Publisher's Note}

Springer Nature remains neutral with regard to jurisdictional claims in published maps and institutional affiliations.

\section{Submit your manuscript to a SpringerOpen ${ }^{\mathcal{O}}$ journal and benefit from:}

- Convenient online submission

- Rigorous peer review

- Open access: articles freely available online

- High visibility within the field

- Retaining the copyright to your article

Submit your next manuscript at $\boldsymbol{\nabla}$ springeropen.com 